\title{
Biomonitoring of mercury, cadmium, and lead exposure in Japanese children: a cross-sectional study
}

\author{
Cimi Ilmiawati - Takahiko Yoshida Toshihiro Itoh $\cdot$ Yoshihiko Nakagi • \\ Yasuaki Saijo • Yoshihiko Sugioka • Mineshi Sakamoto • \\ Akihiko Ikegami $\cdot$ Masanori Ogawa $\cdot$ Fujio Kayama
}

Received: 27 August 2014/Accepted: 18 September 2014/Published online: 8 October 2014

(C) The Japanese Society for Hygiene 2014

\begin{abstract}
Objectives To measure current $\mathrm{Hg}, \mathrm{Cd}$, and $\mathrm{Pb}$ exposure in Japanese children, and to estimate dietary intakes of foods responsible for high body burden.

Methods Blood, hair, and urine samples were collected from 9 to 10-year-old 229 children in Asahikawa and measured for $\mathrm{Hg}, \mathrm{Cd}$, and $\mathrm{Pb}$ in these matrices. Diet history questionnaire was used to estimate intake of marine foods and other food items. Hg level was measured by cold vapor atomic absorption spectrometry. $\mathrm{Cd}$ and $\mathrm{Pb}$ levels were determined with inductively coupled plasma mass spectrometry.

Results Geometric mean (GM) of blood $\mathrm{Hg}, \mathrm{Cd}$, and $\mathrm{Pb}$ was $4.55 \mu \mathrm{g} / \mathrm{L}, 0.34 \mu \mathrm{g} / \mathrm{L}$, and $0.96 \mu \mathrm{g} / \mathrm{dL}$, respectively. Urinary Cd level was $0.34 \mu \mathrm{g} / \mathrm{g}$ creatinine (GM) and hair $\mathrm{Hg}$ was $1.31 \mu \mathrm{g} / \mathrm{g}(\mathrm{GM})$. Approximately one-third (35\%) of blood samples had $\mathrm{Hg}$ level above the U.S. EPA reference dose (RfD; $5.8 \mu \mathrm{g} / \mathrm{L})$. Hair Hg level exceeded U.S. EPA RfD $(1.2 \mu \mathrm{g} / \mathrm{g})$ in $59 \%$ samples. Children in the
\end{abstract}

C. Ilmiawati · A. Ikegami · M. Ogawa $\cdot$ F. Kayama $(\bowtie)$

Department of Environmental and Preventive Medicine, Jichi Medical University School of Medicine,

3311-1 Yakushiji, Shimotsuke, Tochigi 329-0498, Japan

e-mail: kayamaf@jichi.ac.jp

C. Ilmiawati

Department of Pharmacology, Faculty of Medicine Andalas

University, Padang, West Sumatra, Indonesia

T. Yoshida - T. Itoh · Y. Nakagi · Y. Saijo · Y. Sugioka

Department of Health Science, Asahikawa Medical University,

Asahikawa, Hokkaido, Japan

M. Sakamoto

Department of Epidemiology, National Institute for Minamata

Disease, Minamata, Kumamoto, Japan upper quartile of blood $\mathrm{Hg}$ level had significantly higher intake of large predatory fish species compared to those in the lower quartile of blood $\mathrm{Hg}$.

Conclusions Those with high blood $\mathrm{Hg}$ level may be explained by more frequent intake of big predatory fish. $\mathrm{Cd}$ and $\mathrm{Pb}$ exposure is generally low among Japanese children. As no safety margin exists for $\mathrm{Pb}$ exposure and high exposure to $\mathrm{MeHg}$ is noted in Japanese population; periodic biomonitoring and potential health risk assessment should continue in high-risk populations, notably among children.

Keywords Lead $\cdot$ Mercury $\cdot$ Cadmium $\cdot$ Children $\cdot$ Fish intake

\section{Introduction}

Health implications of low-level chronic exposure to toxic metals such as mercury $(\mathrm{Hg})$, cadmium $(\mathrm{Cd})$, and lead $(\mathrm{Pb})$ are contemporary issues in environmental health. Mercury, in the form of methylmercury $(\mathrm{MeHg})$, and $\mathrm{Pb}$ are wellknown neurodevelopmental toxicants, while $\mathrm{Cd}$ is a toxic metal with the main adverse effect in kidney and bone metabolism [1]. Epidemiological evidences have also indicated the potential link between $\mathrm{Cd}$ exposure and neurotoxicity in exposed adults [2] and neurodevelopmental outcomes in children [3, 4].

Environmental exposure to $\mathrm{Hg}, \mathrm{Cd}$, and $\mathrm{Pb}$ may occur simultaneously from various sources and these pollutants may interact to induce early effects in children, with kidney and central nervous system as the most sensitive target organs [5]. Absorbed $\mathrm{Cd}$ is retained mainly in the kidney with a biological half time of around $10-30$ years [6]. $\mathrm{Pb}$ from blood is incorporated into calcified tissues such as 
bone and teeth with half-life in bone ranging from 10 to 30 years. The long biological half-life of these heavy metals leads to accumulation in the body on continuous exposure, which later serves as the source of "endogenous contamination", where stored metals are continually released back into the blood compartment [7].

The fetus, the newborn and children are particularly susceptible to toxic metals exposure because of the sensitivity of the developing nervous system. Children are also susceptible because of their higher intestinal absorption, lower renal excretion than adults. They are exposed to higher dose of toxicant relative to their body weight and having more years of future life where the adverse effect of toxicants may manifest [8].

While the effect of exposure to high level of $\mathrm{MeHg}$ in prenatal period is evident from Minamata disease [9], the general Japanese population is exposed to daily low-level $\mathrm{MeHg}$ through consumption of marine fish and shellfish. Since MeHg is a persistent pollutant that bioaccumulates and biomagnifies through food webs, big predatory fish such as shark, swordfish, and large tuna contain high $\mathrm{MeHg}$ level [10]. Environmental exposure to $\mathrm{Cd}$ is mainly from consumption of agricultural crops (such as leafy vegetables, potatoes, and grains) and from inhalation of tobacco smoke [11], while exposure to $\mathrm{Pb}$ is mainly from contaminated soils and house dust [12].

School-age children are at the greatest susceptibility to suffer the cognitive deficits and behavioral problems from $\mathrm{Pb}$ exposure [13]. In case of $\mathrm{Hg}, \mathrm{MeHg}$ exposure in Japanese adult and infant population has been widely studied [14-16]. However, there is paucity in studies focusing on school-age children. Since exposure to $\mathrm{MeHg}, \mathrm{Cd}$, and $\mathrm{Pb}$ may occur early in the prenatal period and continue throughout a person's life, biomonitoring of exposure level in different age groups is required to understand the spectrum of these toxic metals' health impact.

To estimate the exposure of school-age Japanese children to combined heavy metals, biomonitoring of $\mathrm{Hg}, \mathrm{Cd}$, and $\mathrm{Pb}$ levels in blood, hair, and urine of the children from Asahikawa city was conducted. Asahikawa is located in the middle of Hokkaido, recognized as a major center of agriculture, forestry, a few industries, with limited mining activities even in the past. As we expected a lower intake of marine fish and lower body burden of industrial contaminants among the inhabitants, we chose children in Asahikawa as the subjects in this study.

To predict the relative contribution of dietary route in heavy metals exposure, data on the intake of food items, including fish and other marine products in Asahikawa children were also collected. Information gained from this study will fill the gap in data on toxic metals exposure in school-age children from Japan.

\section{Materials and methods}

\section{Subjects}

Parents with children age 9-10 years old were invited to join the study through schools, community newspaper and a pediatric clinic in Asahikawa in the spring of 2008 and 2009. As an incentive for their participation, they were offered free screening for IgE against white birch (Betula platyphylla) pollen, Japanese cedar (Cryptomeria japonica) pollen, and food allergens. This incentive was based on the fact that $60 \%$ of the children or their siblings had history of hay fever or food allergy, but were otherwise healthy. Written informed consent obtained from the parents or guardians of 229 children and biological samples (blood, hair, and urine) were collected. The Committee of Medical Ethics in Epidemiological Studies of Jichi Medical University and Asahikawa Medical College approved the study protocol. The results of the study together with pertinent lifestyle recommendations were communicated at individual and collective level.

\section{Diet history questionnaire}

To assess the nutritional intake of the subjects, the parents/ guardians filled out semi-quantitative diet history questionnaires (DHQs) [17], which were later verified by a dietitian. The self-administered DHQ is a 16-page structured questionnaire that includes sections on: (1) General dietary behaviors; (2) Major cooking methods; (3) Semiquantitative frequency of intake of 121 selected food and non-alcoholic beverage items; (4) Dietary supplements intake; (5) Consumption frequency and amount of 19 staple foods (rice, bread, noodles, and other wheat foods) and miso (fermented soybean paste) soup; and (6) Open-ended items for foods consumed regularly (less than 1 time/week) that were not otherwise covered by the DHQ. The food and beverage items and portion sizes in the DHQ were derived primarily from data in the National Nutrition Survey of Japan 2002 [18] and several recipe books for Japanese dishes [17]. Detailed descriptions of the methods used for calculating dietary intake and the validity of the DHQ have been published elsewhere [17, 19, 20].

Based on nutritional values of fish, the fish section in the DHQ consisted of white-flesh fish (sea bream, flounder), red-flesh fish (bonito, tuna) and blue-backed fish (sardine, mackerel, herring, perch and anchovy). In addition, a supplementary questionnaire was also given to cover the consumption of fish species and seaweed otherwise not covered in the DHQ. The items covered by the supplementary questionnaire were selected based on accumulated contaminants and included 20 species of fish, whale meat, 
Table 1 Fish and seaweed included in the supplementary questionnaire

\begin{tabular}{|c|c|c|c|}
\hline $\begin{array}{l}\text { Japanese } \\
\text { name }\end{array}$ & English name & Binomial name & Category \\
\hline $\begin{array}{l}\text { Hon } \\
\text { maguro }\end{array}$ & Bluefin tuna & $\begin{array}{l}\text { Thunnus } \\
\text { orientalis }\end{array}$ & Large tuna \\
\hline $\begin{array}{l}\text { Minami } \\
\text { maguro }\end{array}$ & $\begin{array}{l}\text { Southern bluefin } \\
\text { tuna }\end{array}$ & $\begin{array}{l}\text { Thunnus } \\
\text { maccoyii }\end{array}$ & \\
\hline Mekajiki & Swordfish & Xiphias gladius & \\
\hline Makajiki & Billfish/marlin & Istiophoridae & \\
\hline Kihada & Yellowfin tuna & $\begin{array}{l}\text { Thunnus } \\
\text { albacares }\end{array}$ & Small tuna \\
\hline Mebachi & Bigeye tuna & Thunnus obesus & \\
\hline Kinme & Splendid alfonsino & Beryx splendens & Deep sea \\
\hline Ankou & Monkfish & Lophiidae & fish \\
\hline Karei & Righteye flounder & Pleuronectinae & Flatfish \\
\hline Hirame & Large-tooth flounder & Paralichthyidae & \\
\hline Mouka & Salmon shark & Lamna ditropis & Others \\
\hline Sanma & $\begin{array}{l}\text { Pacific saury, } \\
\text { mackerel pike }\end{array}$ & Cololabis saira & \\
\hline Kampachi & Greater amberjack & Seriola dumerili & \\
\hline Buri & Five-ray yellowtail & $\begin{array}{l}\text { Seriola } \\
\quad \text { quinqueradiata }\end{array}$ & \\
\hline Hokke & Arabesque greenling & $\begin{array}{l}\text { Pleurogrammus } \\
\text { azonus }\end{array}$ & \\
\hline Sake & Salmon & $\begin{array}{l}\text { Oncorhynchus } \\
\text { keta }\end{array}$ & \\
\hline Shishamo & Shishamo & $\begin{array}{l}\text { Spirinchus } \\
\quad \text { lanceolatus }\end{array}$ & \\
\hline Saba & Mackerel & $\begin{array}{l}\text { Scomber } \\
\text { japonicus }\end{array}$ & \\
\hline Aji & $\begin{array}{c}\text { Japanese jack } \\
\text { mackerel }\end{array}$ & $\begin{array}{l}\text { Trachurus } \\
\text { japonicus }\end{array}$ & \\
\hline Ayu & Ayu & $\begin{array}{l}\text { Plecoglossus } \\
\text { altivelis }\end{array}$ & $\begin{array}{l}\text { Freshwater } \\
\text { fish }\end{array}$ \\
\hline Kujira & Whale & Cetacea & $\begin{array}{l}\text { Sea } \\
\text { mammal }\end{array}$ \\
\hline Hotategai & Japanese scallop & $\begin{array}{l}\text { Mizuhopecten } \\
\text { yessoensis }\end{array}$ & Bivalve \\
\hline Sazae & Horned turban & Turbo cornutus & Molluscs \\
\hline Wakame & Wakame & $\begin{array}{l}\text { Undaria } \\
\text { pinnatifida }\end{array}$ & Seaweed \\
\hline Kombu & Kelp & Laminariaceae & \\
\hline Mozuku & Mozuku & $\begin{array}{l}\text { Nemacystus } \\
\text { decipiens }\end{array}$ & \\
\hline Hijiki & Hijiki & $\begin{array}{l}\text { Sargassum } \\
\text { fusiforme }\end{array}$ & \\
\hline
\end{tabular}

2 species of shellfish, and 4 species of seaweed (wakame, kelp, mozuku, and hijiki) (see Table 1).

The portion sizes of fish and seaweed were assigned as $80 \mathrm{~g}$ and $10 \mathrm{~g}$, respectively, based on the reports of average one-time intake amounts in the National Nutrition Survey of Japan 2002 [18]. The intake of each food item was normalized to the expected daily energy requirement, based on gender, age, and physical activity level, to avoid under-/over-reported bias. Then, the energy requirementadjusted values $(/ 1000 \mathrm{kcal})$ were used for the statistical analyses.

\section{Covariates}

Age (month) and body mass index (BMI; $\mathrm{kg} / \mathrm{m}^{2}$ ) were calculated. BMI was classified based on age and sex percentiles [21]. Exposure to secondhand smoke was determined by asking whether anybody living in the child's household smoked.

Blood, urine, and hair sampling and analyses

\section{Biological samples collection}

On arrival of the study subjects at a local community hall, urine samples were collected in a plastic tube acidified with nitric acid to stabilize the metals. Blood samples from venipuncture were collected into vacuum heparin-coated glass tubes. Samples were stored at $-80{ }^{\circ} \mathrm{C}$ until analysis. Hair samples were obtained by cutting $3 \mathrm{~cm}$ strands of hair next to the scalp from the occipital area. Hair samples were washed with detergent and rinsed two times with acetone. Hair samples were stored at $5{ }^{\circ} \mathrm{C}$ until measurement of the metals.

\section{$H g$ determination in hair and blood samples}

Total $\mathrm{Hg}$ in 5-10 mg hair samples and in $0.5 \mathrm{~g}$ of whole blood was determined by cold vapor atomic absorption spectrometry (CVAAS) according to the method of Akagi and Nishimura [22]. Hair and blood samples were analyzed at the National Institute for Minamata Disease (Kumamoto, Japan) and IDEA Consultants (Shizuoka, Japan), respectively. Hair samples were digested with $\mathrm{HNO}_{3}, \mathrm{HClO}_{4}$, and $\mathrm{H}_{2} \mathrm{SO}_{4}$ followed by reduction to $\mathrm{Hg}^{0}$ by $\mathrm{SnCl}_{2}$. The limit of detection (LOD) for $\mathrm{Hg}$ in blood was $0.2 \mu \mathrm{g} / \mathrm{L}$ and in hair was $0.01 \mu \mathrm{g} / \mathrm{g}$. Accuracy of determination was confirmed using certified reference materials from National Institute for Environmental Studies, Tsukuba, Japan (NIES CRM No. 13 human hair) and NycoMed, Oslo, Norway (Level 2, Lot. MR9067 human blood). The mean levels of $\mathrm{Hg}$ in hair and blood reference materials were $4.32 \mu \mathrm{g} / \mathrm{g}$ (recommended range: $4.22-4.62 \mu \mathrm{g} / \mathrm{g}$ ) and $7.5 \mu \mathrm{g} / \mathrm{L}$ (recommended range: $6.8-8.5 \mu \mathrm{g} / \mathrm{L}$ ), respectively. The precision of the method, expressed as a coefficient of variation, was $0.8 \%$. Hg levels were expressed as concentrations $(\mu \mathrm{g} / \mathrm{g}$ of hair or $\mu \mathrm{g} / \mathrm{L}$ of blood). 


\section{$\mathrm{Cd}$ and $\mathrm{Pb}$ determination in blood and urine samples}

Blood $\mathrm{Cd}$, blood $\mathrm{Pb}$, and urinary $\mathrm{Cd}$ were analyzed by IDEA Consultants (Shizuoka, Japan) using inductively coupled plasma mass spectrometry (ICPMS). Standards for $\mathrm{Cd}$ and $\mathrm{Pb}$ were purchased from Wako (Osaka, Japan). As an internal standard, mixture solution of yttrium (Y) (Wako) and indium (In) (Kanto Chemical, Tokyo, Japan) was added to the sample solution after dilution with $3 \%$ nitric acid.

To measure $\mathrm{Cd}$ and $\mathrm{Pb}$ in blood, $0.5 \mathrm{~mL}$ blood samples were digested with $2 \mathrm{~mL}$ nitric acid in a microwave digestion system (MDS-2000; CEM, NC, USA), and diluted with ultra-pure water from Milli-Q Gradient A-10 (Millipore, MA, USA) for analysis. Limit of quantification (LOQ) for $\mathrm{Cd}$ and $\mathrm{Pb}$ in blood was $0.3 \mu \mathrm{g} / \mathrm{L}$ and $0.3 \mu \mathrm{g} / \mathrm{dL}$, respectively. Accuracy of measurement was checked by measuring reference blood materials, Sero WB-L2 (Lot. 0503109) for Cd and Sero WB-L1 (Lot. MR4206) for Pb (Nycomed, Oslo, Norway). The mean levels in the reference materials were measured as $5.4 \mu \mathrm{g} / \mathrm{L}$ (recommended range: $2.8-7.4 \mu \mathrm{g} / \mathrm{L}$ ) for $\mathrm{Cd}$ and $29.7 \mu \mathrm{g} / \mathrm{L}$ (recommended range: $26.2-29.0 \mu \mathrm{g} / \mathrm{L}$ ) for $\mathrm{Pb}$.

To measure urinary $\mathrm{Cd}, 0.4 \mathrm{~mL}$ urine samples were digested with $0.2 \mathrm{~mL}$ nitric acid in $80{ }^{\circ} \mathrm{C}$ for $60 \mathrm{~min}$, diluted up to $4 \mathrm{~mL}$ with ultra-pure water, and followed by analysis with ICPMS 7500c (Agilent Technologies, CA, USA). LOQ for $\mathrm{Cd}$ in urine was $0.2 \mu \mathrm{g} / \mathrm{L}$. A reference material for urine, Medisafe Metalle U-L1 (Lot. 05403) (Medichem Diagnostica, Steinenbronn, Germany), was used to check accuracy of $\mathrm{Cd}$ measurement. The mean $\mathrm{Cd}$ level measured in the reference material was $12.6 \mu \mathrm{g} / \mathrm{L}$ (recommended range: $8.5-17.5 \mu \mathrm{g} / \mathrm{L}$ ).

\section{Statistical analyses}

Samples with metals concentration below the LOQ were assigned the value of LOQ divided by the square root of 2 . Levels of blood $\mathrm{Cd}$ and urinary $\mathrm{Cd}$ were below the LOQ in 27 and $43 \%$ of sample, respectively. Data of $\mathrm{Hg}, \mathrm{Cd}$, and $\mathrm{Pb}$ were available from all participants $(n=229)$, except for urinary $\mathrm{Cd}$, for which 3 data points were missing $(n=226)$. Mann-Whitney $U$ tests were performed to compare the $\mathrm{Hg}, \mathrm{Cd}$ and $\mathrm{Pb}$ levels between boys and girls, and were performed to compare the dietary variables between lower and upper blood $\mathrm{Hg}$ quartile groups. Variables with non-normal distribution underwent natural $\log$ transformation before included in the correlation or regression analysis. Variables statistically significantly associated with $\mathrm{Hg}$ or $\mathrm{Cd}$ level in Pearson's correlation were included as independent variables. Multiple regression analyses were performed to identify dietary predictors of $\mathrm{Hg}$ and Cd levels, adjusted with age, sex, and BMI. IBM SPSS statistical software version 19.0 (IBM, Inc.) was used for the analyses. A $p$ value of less than 0.05 (two-sided test) was considered statistically significant.

\section{Results}

Subjects characteristics

Information on characteristics of Asahikawa children is shown in Table 2. Total participants were 229 with similar proportion of boys and girls. BMI calculation based on CDC percentile for age and sex showed that $71 \%$ of the children were normoweight and $27 \%$ were overweight or obese. Forty-two percent of the children were exposed to secondhand smoking at home at the time of interview, with more girls exposed (48\%) than boys $(37 \%)$.

$\mathrm{Hg}, \mathrm{Cd}$, and $\mathrm{Pb}$ levels in Asahikawa children

The heavy metal levels in blood, urine, and hair of Asahikawa children are shown in Table 3 with further comparison between genders.

\section{Blood}

$\mathrm{Hg}, \mathrm{Cd}$, and $\mathrm{Pb}$ levels were examined in blood samples. The geometric mean (GM) of $\mathrm{HgB}$ was $4.55 \mu \mathrm{g} / \mathrm{L}$ with no statistically significant difference between genders $(p=0.12)$. The range of $\mathrm{HgB}$ value was $1.16-15.79 \mu \mathrm{g} / \mathrm{L}$, with $35 \%$ samples had values above the U.S. EPA RfD $(5.8 \mu \mathrm{g} / \mathrm{L})$. The distribution of $\mathrm{HgB}$ level in this population

Table 2 Characteristics of Asahikawa children

\begin{tabular}{lcrr}
\hline & \multicolumn{1}{c}{ All } & \multicolumn{1}{c}{ Boys } & \multicolumn{1}{c}{ Girls } \\
\hline Number (\%) & $229(100)$ & $118(52)$ & $111(48)$ \\
Age in month (mean (SD)) & $108.9(3.6)$ & $109.1(3.5)$ & $108.7(3.7)$ \\
Height in cm (mean (SD)) & $137.3(6.1)$ & $137.1(6.0)$ & $137.5(6.2)$ \\
Weight in kg (mean (SD)) & $33.6(7.4)$ & $34(7.6)$ & $33.1(7.1)$ \\
& & & \\
BMI ( $n(\%))$ & & & \\
Underweight (<5th & $4(2)$ & $1(1)$ & $3(3)$ \\
$\quad$ percentile) & $162(71)$ & $81(69)$ & $81(73)$ \\
Normal (5th-<85th) & $47(20)$ & $27(23)$ & $20(18)$ \\
Overweight (85th-<95th) & $16(7)$ & $9(7)$ & $7(6)$ \\
Obese $(\geq 95$ th) & & & \\
Secondhand smoke exposure $(n(\%))$ & & \\
No & $132(58)$ & $74(63)$ & $58(52)$ \\
Yes & $97(42)$ & $44(37)$ & $53(48)$ \\
\hline
\end{tabular}

$S D$ standard deviation, $B M I$ body mass index 
is shown in Fig. 1a (with rounding of the decimal values). For blood $\mathrm{Cd}(\mathrm{CdB}), 61(27 \%)$ samples were below the LOQ. The GM CdB was $0.34 \mu \mathrm{g} / \mathrm{L}$. The median concentration of $\mathrm{CdB}$ was significantly higher in girls than boys $(p=0.01)$. Blood lead $(\mathrm{PbB})$ level in this population ranged from 0.41 to $3.00 \mu \mathrm{g} / \mathrm{dL}$ with no statistically significant difference across gender $(p=0.28)$.
Urine

Forty-three percent of urine samples showed urinary $\mathrm{Cd}$ (CdU) concentration below the LOQ. The GM CdU in this population was $0.21 \mu \mathrm{g} / \mathrm{L}(0.34 \mu \mathrm{g} / \mathrm{g}$ creatinine $)$. No statistically significant difference was observed between genders $(p=0.15)$.

Table 3 Heavy metal levels in blood, urine, and hair of Asahikawa children

\begin{tabular}{|c|c|c|c|c|c|c|c|c|c|}
\hline \multirow{3}{*}{$\begin{array}{l}\text { Parameters } \\
\mathrm{HgB}(\mu \mathrm{g} / \mathrm{L})\end{array}$} & \multicolumn{6}{|c|}{ All $(n=229)$} & \multirow{3}{*}{$\begin{array}{l}\text { Boys }(n=118) \\
\text { Median }(\mathrm{IQR}) \\
4.92(3.37)\end{array}$} & \multirow{3}{*}{$\begin{array}{l}\text { Girls }(n=111)^{*} \\
\text { Median }(\mathrm{IQR}) \\
4.59(3.11)\end{array}$} & \multirow{3}{*}{$\frac{p \text { value** }}{0.12}$} \\
\hline & \multirow{2}{*}{$\frac{\text { Mean (SD) }}{5.11(2.49)}$} & \multirow{2}{*}{$\begin{array}{l}\text { Geometric mean } \\
4.55\end{array}$} & \multirow{2}{*}{$\frac{\text { Median (IQR) }}{4.65(3.09)}$} & \multicolumn{3}{|c|}{ Min-Max } & & & \\
\hline & & & & 1.16 & - & 15.79 & & & \\
\hline $\mathrm{CdB}(\mu \mathrm{g} / \mathrm{L})$ & $0.36(0.12)$ & 0.34 & $0.35(0.20)$ & $<\mathrm{LOQ}$ & - & 0.87 & $0.34(0.18)$ & $0.37(0.14)$ & 0.01 \\
\hline $\mathrm{PbB}(\mu \mathrm{g} / \mathrm{dL})$ & $1.00(0.32)$ & 0.96 & $0.96(0.41)$ & 0.41 & - & 3.00 & $0.94(0.44)$ & $0.98(0.39)$ & 0.28 \\
\hline $\mathrm{CdU}(\mu \mathrm{g} / \mathrm{L})$ & $0.28(0.19)$ & 0.21 & $0.23(0.22)$ & $<\mathrm{LOQ}$ & - & 1.57 & $0.22(0.20)$ & $0.25(0.23)$ & 0.61 \\
\hline $\mathrm{CdU}(\mu \mathrm{g} / \mathrm{g} \mathrm{cr})$ & $0.40(0.36)$ & 0.34 & $0.33(0.20)$ & 0.13 & - & 4.67 & $0.30(0.18)$ & $0.35(0.23)$ & 0.15 \\
\hline $\mathrm{HgH}(\mu \mathrm{g} / \mathrm{g})$ & $1.49(0.77)$ & 1.31 & $1.40(0.98)$ & 0.31 & - & 3.96 & $1.44(1.03)$ & $1.31(0.87)$ & 0.43 \\
\hline
\end{tabular}

* Except for CdU $(n=108)$

** Mann-Whitney $U$ test

$H g B$ blood mercury, $C d B$ blood cadmium, $P b B$ blood lead, $C d U$ urine cadmium, $c r$ creatinine, $H g H$ hair mercury, $L O Q$ limit of quantification, $S D$ standard deviation, IQRs interquartile range

Fig. 1 a Distribution of blood $\mathrm{Hg}$ levels in Asahikawa children. b Distribution of hair $\mathrm{Hg}$ levels in Asahikawa children. c Association between blood and hair Hg levels in Asahikawa children
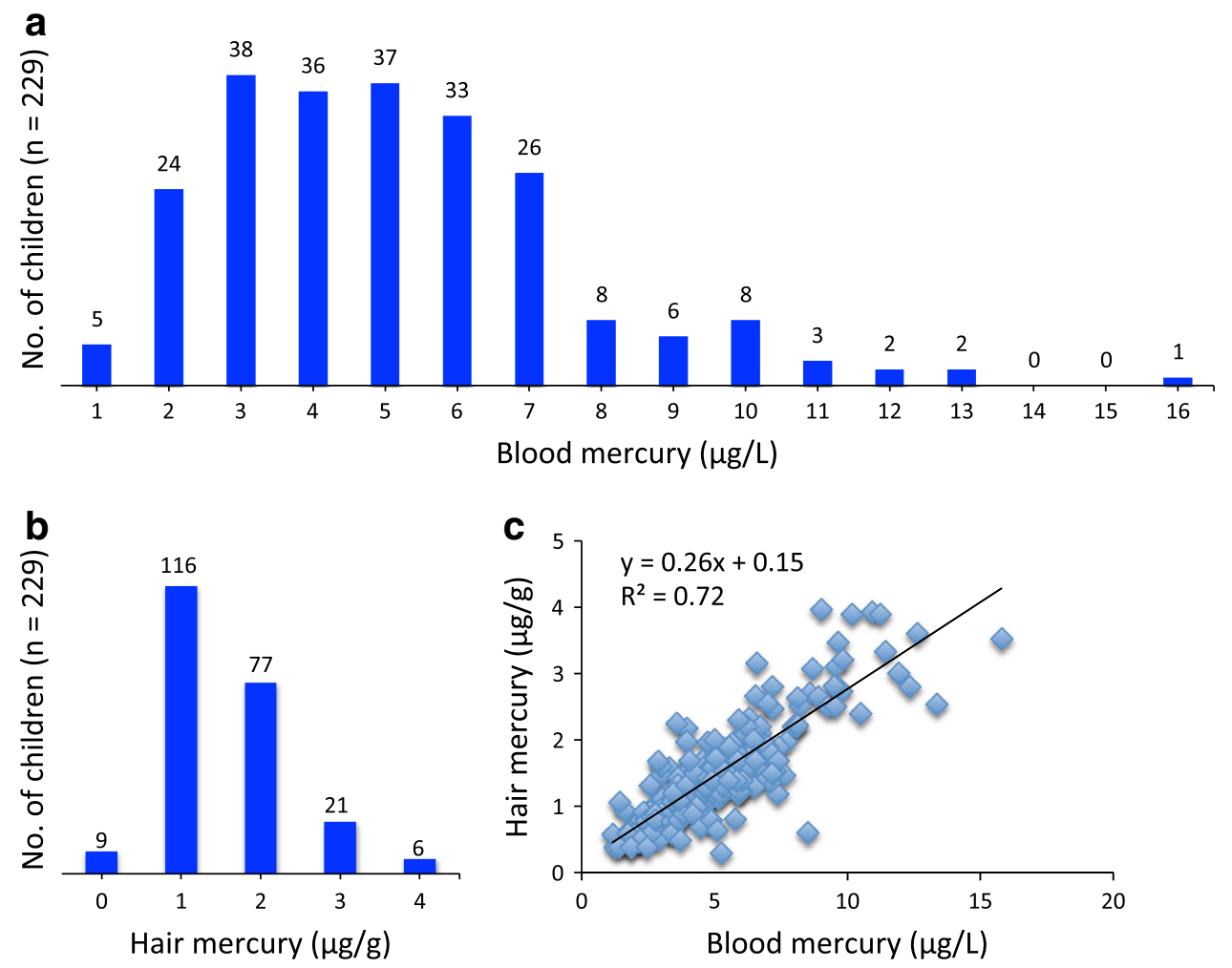


\section{c. Hair}

Hair mercury (HgH) levels ranged from 0.31 to $3.96 \mu \mathrm{g} / \mathrm{g}$ with $59 \%$ children having $\mathrm{HgH}$ above U.S. EPA RfD of $1.2 \mu \mathrm{g} / \mathrm{g}$. No difference in $\mathrm{HgH}$ level was observed between boys and girls $(p=0.43)$. The distribution of $\mathrm{HgH}$ levels is shown in Fig. 1b (with rounding of the decimals).

Dietary intake of foods with relevance to toxic metals exposure

\section{Dietary intake in children with low and high blood mercury level}

The dose-effect relationships between dietary intake and blood mercury levels were assessed indirectly by dividing the children into quartiles of $\mathrm{HgB}$. The same analysis was not performed on $\mathrm{HgH}$ because it is highly correlated with $\mathrm{HgB}$ (Fig. 1c).

Table 4 shows the energy-adjusted median level of daily intake of fish, seaweed, and major food groups (cereals, meat, fruits, vegetables), as well as omega-3 polyunsaturated fatty acid (n3-PUFA). Subjects in the upper quartile of $\mathrm{HgB}(n=57)$ generally had higher intake of these dietary variables than subjects in the lower quartile ( $n=57)$, although in most comparisons the $p$ value for the differences was greater than 0.05 . Subjects in upper quartile of $\mathrm{HgB}$ had statistically significant daily intake of large tuna $(p<0.001)$, alfonsino $(p=0.02)$, monkfish $(p<0.001)$, kelp $(p=0.003)$, and total fish intake $(p<0.001)$ than subjects in the lower quartile of $\mathrm{HgB}$.

\section{b. Sex difference in food intake}

To examine the potential contribution of differing food intake in differing levels of metals between genders, sex difference in food intake was analyzed (Table 5). There was no statistically significant difference in total cereals (consisting primarily of rice), total fruits, and total vegetables intake. Total seafood intake was slightly higher in boys, but the difference fell short of significance $(p=0.09)$. The boys consumed significantly more meat $(p<0.001)$ and less seaweed $(p<0.01)$ than did the girls.

\section{Predictors of heavy metal levels}

To identify dietary intake associated with mercury and cadmium levels, multiple regression analyses were performed (Table 6). Age (month), sex, and BMI $\left(\mathrm{kg} / \mathrm{m}^{2}\right)$ were included as confounders. For cadmium analyses, secondhand smoke exposure was also included in the
Table 4 Median intake of dietary variable in lower quartile and upper quartile of $\mathrm{HgB}$

\begin{tabular}{|c|c|c|c|}
\hline \multirow{2}{*}{$\begin{array}{l}\text { Dietary } \\
\text { variable }\end{array}$} & \multicolumn{2}{|c|}{ Median intake (g/1000 kcal) } & \multirow[t]{2}{*}{$p$ value* } \\
\hline & $\begin{array}{l}\text { Lower quartile } \\
\mathrm{HgB} \\
n=57\end{array}$ & $\begin{array}{l}\text { Upper quartile } \\
\mathrm{HgB} \\
n=114\end{array}$ & \\
\hline Large tuna & 0.8 & 5.4 & $<0.001$ \\
\hline Small tuna & 0.0 & 0.2 & 0.28 \\
\hline Alfonsino & 0.0 & 0.0 & 0.02 \\
\hline Yellowtail & 5.5 & 7.8 & 0.43 \\
\hline Salmon & 0.0 & 0.0 & 0.95 \\
\hline Monkfish & 0.9 & 6.3 & $<0.001$ \\
\hline Total fish & 22.4 & 28.2 & $<0.001$ \\
\hline Wakame & 0.2 & 0.2 & 0.57 \\
\hline Kelp & 0.0 & 0.0 & 0.003 \\
\hline Mozuku & 0.3 & 0.3 & 0.60 \\
\hline Hijiki & 1.7 & 2.0 & 0.18 \\
\hline Cereals & 173.2 & 181.6 & 0.52 \\
\hline Meat & 35.9 & 37.2 & 0.92 \\
\hline Fruits & 38.2 & 46.6 & 0.14 \\
\hline Vegetables & 31.4 & 35.0 & 0.47 \\
\hline Total seaweed & 2.5 & 3.1 & 0.11 \\
\hline n3-PUFA & 1.1 & 1.2 & 0.15 \\
\hline
\end{tabular}

* Mann-Whitney $U$ test

Table 5 Sex difference in food intake

\begin{tabular}{|c|c|c|c|c|}
\hline $\begin{array}{l}\text { Food intake } \\
(\mathrm{g} / 1000 \mathrm{kcal})\end{array}$ & $\begin{array}{l}\text { All } \\
(n=229) \\
\text { Median } \\
(\text { IQR })\end{array}$ & $\begin{array}{l}\text { Boys } \\
(n=118) \\
\text { Median } \\
(\mathrm{IQR})\end{array}$ & $\begin{array}{l}\text { Girls } \\
(n=111) \\
\text { Median } \\
(\text { IQR })\end{array}$ & $p$ value $^{\mathrm{a}}$ \\
\hline Total cereals & $176.7(68.2)$ & $172.6(72.4)$ & $180.0(63.4)$ & 0.61 \\
\hline Total seafood & $26.5(14.4)$ & $28.0(13.3)$ & $24.1(14.3)$ & 0.09 \\
\hline Total meat & $35.9(24.3)$ & $39.7(25.4)$ & $31.2(21.8)$ & $<0.001$ \\
\hline $\begin{array}{l}\text { Total } \\
\text { seaweed }\end{array}$ & $2.8(3.2)$ & $2.5(2.6)$ & $3.2(3.2)$ & $<0.01$ \\
\hline Total fruits & $44.0(48.8)$ & $42.5(51.6)$ & $47.5(46.3)$ & 0.16 \\
\hline $\begin{array}{l}\text { Total } \\
\text { vegetables }\end{array}$ & $33.7(25.6)$ & $31.9(26.2)$ & $36.5(25.3)$ & 0.43 \\
\hline
\end{tabular}

a Mann-Whitney $U$ test for sex difference

independent variables. Large tuna intake predicted $\mathrm{HgB}$ $(p<0.001)$ and $\mathrm{HgH}(p<0.05)$ levels and $\mathrm{HgB}$ level was the best predictor for $\mathrm{HgH}$ level $(p<0.001)$. Total seafood intake was the best predictor for $\mathrm{CdB}(p<0.01)$. CdU level was statistically significantly predicted by cereals and kelp intake (both $p<0.05$ ). Secondhand smoke exposure did not significantly predict cadmium level in blood or urine, neither did it predict blood $\mathrm{Pb}$ level (data not shown). 
Table 6 Predictors of $\mathrm{HgB}, \mathrm{HgH}, \mathrm{CdB}$, and $\mathrm{CdU}$; results of multiple regression analysis

\begin{tabular}{|c|c|}
\hline \multicolumn{2}{|l|}{$\mathrm{HgB}(\mu \mathrm{g} / \mathrm{L})$} \\
\hline Adjusted $R^{2}$ & 0.264 \\
\hline \multicolumn{2}{|l|}{ Standardized $\beta$ coefficient } \\
\hline Total seafood intake $(\mathrm{g} / 1000 \mathrm{kcal})$ & $0.243 * * *$ \\
\hline Large tuna intake $(\mathrm{g} / 1000 \mathrm{kcal})$ & $0.399 * * *$ \\
\hline \multicolumn{2}{|l|}{$\mathrm{HgH}(\mu \mathrm{g} / \mathrm{g})$} \\
\hline Adjusted $R^{2}$ & 0.699 \\
\hline \multicolumn{2}{|l|}{ Standardized $\beta$ coefficient } \\
\hline Total seafood intake $(\mathrm{g} / 1000 \mathrm{kcal})$ & 0.040 \\
\hline Large tuna intake $(\mathrm{g} / 1000 \mathrm{kcal})$ & $0.088^{*}$ \\
\hline $\mathrm{HgB}(\mu \mathrm{g} / \mathrm{L})$ & $0.782 * * *$ \\
\hline \multicolumn{2}{|l|}{$\mathrm{CdB}(\mu \mathrm{g} / \mathrm{L})$} \\
\hline Adjusted $R^{2}$ & 0.063 \\
\hline \multicolumn{2}{|l|}{ Standardized $\beta$ coefficient } \\
\hline Secondhand smoke exposure (no, yes) & 0.043 \\
\hline Cereals intake $(\mathrm{g} / 1000 \mathrm{kcal})$ & 0.040 \\
\hline Meat intake $(\mathrm{g} / 1000 \mathrm{kcal})$ & $-0.129^{\#}$ \\
\hline Total seafood intake $(\mathrm{g} / 1000 \mathrm{kcal})$ & $0.189 * *$ \\
\hline Total seaweed intake $(\mathrm{g} / 1000 \mathrm{kcal})$ & -0.101 \\
\hline \multicolumn{2}{|l|}{$\mathrm{CdU}(\mu \mathrm{g} / \mathrm{g}$ cr $)$} \\
\hline Adjusted $R^{2}$ & 0.059 \\
\hline \multicolumn{2}{|l|}{ Standardized $\beta$ coefficient } \\
\hline Secondhand smoke exposure (no, yes) & -0.127 \\
\hline Cereals intake (g/1000 kcal) & $0.266^{*}$ \\
\hline Kelp intake (g/1000 kcal) & $0.262 *$ \\
\hline
\end{tabular}

$\mathrm{HgB}, \mathrm{HgH}, \mathrm{CdB}, \mathrm{CdU}$ were logarithmically transformed. Total seafood, large tuna, and kelp intake were logarithmically transformed. All analyses included age (month), sex, and BMI as confounders

\# $0.05<p<0.1$; * $p<0.05$; ** $p<0.01$; *** $p<0.001$

\section{Discussion}

$\mathrm{Hg}$

Approximately $95 \%$ of $\mathrm{Hg}$ in blood and $80 \%$ of $\mathrm{Hg}$ in hair is the methylated form [23, 24]. The linear relationship between blood and hair $\mathrm{Hg}$ (Fig. 1c) supports the hypothesis that $\mathrm{MeHg}$ is the main form of $\mathrm{Hg}$ in our samples.

When using the US EPA RfD of $1.2 \mu \mathrm{g} / \mathrm{g}$ for hair $\mathrm{Hg}$ level, $59 \%$ of the subjects have hair $\mathrm{Hg}$ above this level. On the other hand, provisional tolerable weekly intake (PTWI) of MeHg (as revised by FAO/WHO JECFA in 2003 [25] ) is $1.6 \mu \mathrm{g} / \mathrm{kg}$ body weight (JECFA 2003), which corresponds to hair mercury level of $2.2 \mu \mathrm{g} / \mathrm{g}$ [26]. According to this reference level, $15 \%$ of the subjects have hair $\mathrm{Hg}$ above $2.2 \mu \mathrm{g} / \mathrm{g}$. The reference level for hair $\mathrm{Hg}$ in Japan is $3 \mu \mathrm{g} / \mathrm{g}$, based on a safe intake limit of $2.0 \mu \mathrm{g} / \mathrm{kg}$ body weight (FSC, 2005 [27] ). Using this level, only $5.7 \%$ of the subjects had hair $\mathrm{Hg}$ at or above the reference value.
A previous study in 7-year-old Japanese children with median hair Hg 1.65 (range: 0.35-6.32) $\mu \mathrm{g} / \mathrm{g}$ did not find significant association between hair mercury levels and neurodevelopmental variables [28]. A cohort study of $\mathrm{MeHg}$ exposure in Seychelles, a country with high fish consumption similar to that in Japan, did not find any relation between postnatal mercury exposure and academic achievement in 9-year and 17-year-old children [29]. Mean hair $\mathrm{Hg}$ level in that study was $6.09 \mu \mathrm{g} / \mathrm{g}$ at 9 years and $8.0 \mu \mathrm{g} / \mathrm{g}$ at 17 years. The benefit of n3-PUFA content of the fish is hypothesized to outweigh the risk of $\mathrm{MeHg}$ exposure from fish intake [30]. Our findings of median hair $\mathrm{Hg} 1.40$ (range: $0.31-3.96) \mu \mathrm{g} / \mathrm{g}$ are slightly lower than that of previous Japanese study, and mean hair $\mathrm{Hg}$ in our study $(1.49 \mu \mathrm{g} / \mathrm{g})$ is much lower than that of Seychelles cohort. Based on comparison with these two studies, it is likely that the current level of $\mathrm{MeHg}$ exposure in Asahikawa children do not relate to adverse neurodevelopmental effect or scholastic achievement. However, further validation is needed to support this premise.

In concert with previous data, our data confirm that consumption of big predatory fish such as tuna predicts high exposure to $\mathrm{MeHg}$. Fish consumption is widely known to be the most important source of $\mathrm{MeHg}$ exposure in the general population. Prenatal and childhood exposures are particularly of concern due to the susceptibility of the developing brain to this neurotoxicant (WHO 2008 [8] ). Dental amalgam may contribute to blood mercury level. The information on dental amalgam was not collected in the present study. Since the $\mathrm{Hg}$ in dental fillings has been severely restricted in dentistry practice in Japan and only about 2 in 100 people have amalgam fillings [31], it is unlikely that this route contributes to $\mathrm{Hg}$ exposure in the current study's subjects.

\section{$\mathrm{Cd}$}

The urinary $\mathrm{Cd}$ concentration reflects the lifetime body burden and is proportional to the concentration in the kidney. Blood Cd reflects recent and cumulative exposure to $\mathrm{Cd}$ as the half-life of $\mathrm{Cd}$ in blood displays a fast component of 3-4 months and a slow component of about 10 years [6]. The median blood Cd level was significantly higher in girls than in boys (Table 3) and cigarette smoke is a major source of $\mathrm{Cd}$ exposure. However, environmental tobacco smoke exposure did not predict blood $\mathrm{Cd}$ or urinary $\mathrm{Cd}$ level in this study (Table 6). It may reflect the limitations of questionnaire survey to determine passive smoking status and urine cotinine level measurements is the method of choice to resolve this issue, which was unfortunately not performed in this study. Nevertheless, the high percentage of children exposed to secondhand smoke at home reiterates the importance of parents' awareness on 
the danger of environmental tobacco smoke towards children's health.

About one-third of Cd dietary intake in the Japanese population comes from rice consumption [32]. In line with this; cereals intake is found to predict urinary $\mathrm{Cd}$ level. However, total seafood intake rather than cereals intake predicts blood Cd level best (Table 6).

Since Cd bioavailability is affected by low iron status [6], it is possible that blood Cd is higher in the girls due to their lower iron level that enhances intestinal $\mathrm{Cd}$ absorption as opposed to the boys. Significantly higher meat intake (a rich source of dietary iron) in boys also supports this suggestion (Table 5). Assessment of iron status is needed to help explaining the sex difference in blood $\mathrm{Cd}$ levels. Additional explanation for the higher blood $\mathrm{Cd}$ in Asahikawa girls is likely their higher $\mathrm{Cd}$ intake from dietary source, like seaweed, compared to the boys (Table 5). Indeed, seaweed has been shown to have a high metal pollutant accumulation capacity [33].

The amount of $\mathrm{Cd}$ that has accumulated in the kidney is a function of age and/or daily $\mathrm{Cd}$ intake [32]. Current data on urinary $\mathrm{Cd}$ level in 6-year-old Japanese children from Miyagi Prefecture showed the GM of $\mathrm{Cd}$ is $3.16 \mu \mathrm{g} / \mathrm{g}$ creatinine for boys and $2.75 \mu \mathrm{g} / \mathrm{g}$ creatinine for girls [34]. Since our subjects are older, we expected the urinary $\mathrm{Cd}$ would be higher in our study due to increasing body burden with age. Interestingly, our finding in 9-10-year-old children (GM: $0.34 \mu \mathrm{g} / \mathrm{g}$ creatinine) showed much lower urinary $\mathrm{Cd}$ than the prior study. The difference in urinary $\mathrm{Cd}$ may reflect the geographical difference of Miyagi Prefecture and Asahikawa with consequent variation of $\mathrm{Cd}$ in the soils and foods. The difference in Cd intake from food could also suggest the reason for the difference in urinary $\mathrm{Cd}$ levels between Japanese and U.S. children. A report on U.S. children participating in National Health and Nutrition Examination Survey (NHANES) between 1999 and 2004 [35] showed that the median urinary $\mathrm{Cd}$ for $10-11$ years group was $0.107 \mu \mathrm{g} / \mathrm{L}$ (interquartile range: 0.122) [3]. Thus, the urinary $\mathrm{Cd}$ level of Asahikawa children (median: $0.23 \mu \mathrm{g} / \mathrm{L}$, interquartile range: 0.22 ; Table 3 ) in the current study was twice that of the U.S. children. WHO reference value for urinary $\mathrm{Cd}$ level in the context of environmental exposure is $2 \mu \mathrm{g} / \mathrm{g}$ creatinine [36]. Only one subject (a girl) has urinary $\mathrm{Cd}$ above this value in the present study (4.67 $\mu \mathrm{g} / \mathrm{g}$ creatinine). Further examination of dietary pattern is recommended in this subject and, if possible, followed by dietary modification to minimize long-term risk of environmental $\mathrm{Cd}$ exposure.

$\mathrm{Pb}$

Children are most susceptible to the neurobehavioral effects of $\mathrm{Pb}$ exposure. Secondhand smoke exposure has been shown to associate with elevated blood $\mathrm{Pb}$ levels in a national representative of US children from NHANES (1999-2004) even after adjustment for lead in house dust [37]. Median blood $\mathrm{Pb}$ levels in the NHANES study $(1.10 \mu \mathrm{g} / \mathrm{dL})$ are similar to those in the present study $(0.96 \mu \mathrm{g} / \mathrm{dL})$. However, in univariate and multivariate analyses, the association between secondhand smoke exposure and blood $\mathrm{Pb}$ is not found in the current study's subjects. Further study, which measures serum cotinine and house dust lead levels, would help elucidate the contribution of environmental tobacco smoke on blood $\mathrm{Pb}$ levels in Asahikawa children.

Recently, the US CDC lowered the threshold for blood $\mathrm{Pb}$ in children from $<10 \mu \mathrm{g} / \mathrm{dL}$ to $<5 \mu \mathrm{g} / \mathrm{dL}$ (CDC 2012). Mean blood $\mathrm{Pb}$ levels are in the range $2-4 \mu \mathrm{g} / \mathrm{dL}$ in the United States and much of Europe [38]. Blood Pb level has been shown to be very low $(1.07 \mu \mathrm{g} / \mathrm{dL})$ in Japanese children from Tokyo, Shizuoka, and Osaka [39]; our data expand this finding, with Japanese children from Asahikawa showing a similar trend toward low blood $\mathrm{Pb}$ level $(0.96 \mu \mathrm{g} / \mathrm{dL})$. This level is the lowest known amongst developed countries.

Epidemiological evidence shows that there is no safety margin for childhood $\mathrm{Pb}$ exposure, but rather a continuum of toxicity. The benchmark dose (BMD), i.e.: the dose that leads to a loss of $1 \mathrm{IQ}$ point, for $\mathrm{Pb}$ is set at lower confidence limits of $0.1-1.0 \mu \mathrm{g} / \mathrm{dL}$ [40]. If we apply this BMD to the current exposure level of Japanese children $(\sim 1.0 \mu \mathrm{g} / \mathrm{dL})$, the children are at risk of losing 1 IQ point at the least. Therefore, the authority should not be complacent and should maintain and/or intensify current efforts to keep environmental $\mathrm{Pb}$ exposure to a minimum in Japan.

The strengths of this study include the fairly homogenous study population and the use of sensitive methods to determine of $\mathrm{Hg}, \mathrm{Cd}$, and $\mathrm{Pb}$ levels. Moreover, the validated DHQ used in this study covered extensive range of seafood and other food items and all participants completed the DHQ with no missing data points were noted. The use of blood $\mathrm{Cd}$ and blood $\mathrm{Hg}$ as recent exposure metrics also adds the strength to this study. The limitations of this study include the cross-sectional nature of data collection, the limited number of subjects, and the necessarily subjective nature of responses to the DHQ. However, it is considered that the measured internal exposure level is satisfactory in assessing the risk imposed by exposure to $\mathrm{Hg}, \mathrm{Cd}$, and $\mathrm{Pb}$ in this study's population.

In conclusion, the exposure to $\mathrm{MeHg}$ in Japanese children is above the U.S. EPA RfD, which, in part, is explained by their consumption of large predatory fish. $\mathrm{Cd}$ and $\mathrm{Pb}$ exposures are low in this population. However, $\mathrm{Cd}$ may bioaccumulate due to its extremely long biological half-life; no safety margin exists for $\mathrm{Pb}$ exposure; and exposure to $\mathrm{MeHg}$ is expected to continue as a function of 
Japanese dietary habits. Therefore, this study underscores the need to reinforce parental advisory measures regarding seafood choice. Moreover, periodic biomonitoring, together with potential health risk assessments, should be carried out in the future in high-risk populations.

Acknowledgments The research project was supported by a Grantin-Aid for Food Safety from Food Safety Commission of Japan (Grant No. 0602, 2006-2009, "New screening methodology in exposure assessment of contaminant in foods among high-risk subpopulations") and partly by a Grant-in-Aid for Food Safety Research from Ministry of Health, Labor and Welfare (2007-2010). The funding sources had no involvement in the study design; in the collection, analysis, and interpretation of data; and in the writing and publication of the report. The first author gratefully acknowledged the Postgraduate Education Scholarship (2012-2014) from the Ministry of National Education, Republic of Indonesia.

Conflict of interest All the authors have no financial relationship with other organization related to the study subject. Only the governmental grant-in-aids are source of the research budget. The authors declare that they have no conflict of interest.

\section{References}

1. Schoeters G, Den Hond E, Zuurbier M, Naginiene R, Van Den Hazel P, Stilianakis N, et al. Cadmium and children: exposure and health effects. Acta Paediatr Suppl. 2006;95(453):50-4.

2. Viaene MK, Masschelein R, Leenders J, De Groof M, Swerts LJVC, Roels HA. Neurobehavioural effects of occupational exposure to cadmium: a cross sectional epidemiological study. Occup Environ Med. 2000;57:19-27.

3. Ciesielski T, Weuve J, Bellinger DC, Schwartz J, Lanphear B, Wright RO. Cadmium exposure and neurodevelopmental outcomes in U.S. children. Environ Health Perspect. 2012;120:758-63.

4. Kippler M, Tofail F, Hamadani JD, Gardner RM, GranthamMcGregor SM, Bottai M, et al. Early-life cadmium exposure and child development in 5-years old girls and boys: a cohort study in rural Bangladesh. Environ Health Perspect. 2012;120(10):1462-8.

5. de Burbure C, Buchet JP, Leroyer A, Nisse C, Haguenoer JM, Mutti A, et al. Renal and neurologic effects of cadmium, lead, mercury, and arsenic in children: evidence of early effects and multiple interactions at environmental exposure levels. Environ Health Perspect. 2006;114:584-90.

6. Järup L, Åkesson A. Current status of cadmium as an environmental health problem. Toxicol Appl Pharmacol. 2009;238:201-8.

7. Barbosa F Jr, Tanus-Santos JE, Gerlach RF, Parsons PJ. A critical review of biomarkers used for monitoring human exposure to lead: advantages, limitations, and future needs. Environ Health Perspect. 2005;113:1669-74.

8. World Health Organization (2008) Guidance for identifying popuations at risk from mercury exposure. UNEP DTIE Chemicals Branch and WHO Department of Food Safety, Zoonoses and Foodborne Diseases. Available at: http://www.unep.org/hazar doussubstances/Mercury/MercuryPublications/GuidanceTraining materialToolkits/GuidanceforIdentifyingPopulationsatRisk/tabid/ 3616/language/en-US/Default.aspx (2013.7.30).

9. Harada M. Congenital Minamata disease: intrauterine methylmercury poisoning. Teratology. 1978;18(2):285-8.

10. ATSDR (Agency for Toxic Substances and Disease Registry). Toxicological profile for mercury. Atlanta, U. S Department of Health and Human Services, 1999.
11. ATSDR (Agency for Toxic Substances and Disease Registry). Toxicological profile for cadmium. Atlanta, U. S Department of Health and Human Services, 2012.

12. ATSDR (Agency for Toxic Substances and Disease Registry). Toxicological profile for lead. Atlanta, U. S Department of Health and Human Services, 2007.

13. Hornung RW, Lanphear BP, Dietrich KN. Age of greatest susceptibility to childhood lead exposure: a new statistical approach. Environ Health Perspect. 2009;117:1309-12.

14. Sakamoto M, Kubota M, Matsumoto S, Nakano A, Akagi H. Declining risk of methylmercury exposure to infants during lactation. Environ Res. 2002;90:185-9.

15. Sakamoto M, Murata K, Kubota M, Nakai K, Satoh H. Mercury and heavy metal profiles of maternal and umbilical cord RBCs in Japanese population. Ecotox Environ Safe. 2010;73:1-6.

16. Suzuki K, Nakai K, Sugawara T, Nakamura T, Ohba T, Shimada $\mathrm{M}$, et al. Neurobehavioral effects of prenatal exposure to methylmercury and PCBs, and seafood intake: neonatal behavioral assessment scale results of Tohoku study of child development. Environ Res. 2010;110:699-704.

17. Sasaki S, Yanagibori R, Amano K Self-administered diet history questionnaire developed for health education: a relative validation of the test version by comparison with 3-day diet record in women. J Epidemiol (1998a);203-15.

18. National Nutrition Survey (in Japanese) (2002). Available at: http:// www.mhlw.go.jp/houdou/2003/12/h1224-4.html (2013.7.29).

19. Sasaki S, Yanagibori R, Amano K. Validity of a self-administered diet history questionnaire for assessment of sodium and potassium: comparison with single 24-hour urinary excretion. Jpn Circ J. 1998;62:431-5.

20. Sasaki S, Ushio F, Amano K, Morihara M, Todoriki O, Uehara Y, et al. Serum biomarker-based validation of a self-administered diet history questionnaire for Japanese subjects. J Nutr Sci Vitaminol. 2000;46:285-96.

21. CDC (Centers for Disease Control and Prevention) (2012) CDC response to advisory committee on childhood lead poisoning prevention recommendations in "Low level lead exposure harms children: a renewed call of primary prevention." Available at: http://www.cdc.gov/nceh/lead/ACCLPP/CDC_Response_Lead_ Exposure_Recs.pdf (2013.7.29).

22. Akagi H, Nishimura H. Speciation of mercury in the environment. In: Suzuki T, Imura N, Clarkson TW, editors. Advances in mercury toxicology. New York: Plenum; 1991. p. 53-76.

23. Sherlock J, Hislop D, Newton G, Topping G, Whittle K. Elevation of mercury in human blood from controlled ingestion of methylmercury in fish. Hum Exp Toxicol. 1984;3:117-31.

24. Cernichiari E, Brewer R, Myers GJ, Marsh DO, Lapham LW, $\operatorname{Cox} \mathrm{C}$, et al. Monitoring methylmercury during pregnancy: maternal hair predicts fetal brain exposure. Neurotoxicology. 1995; 16:705-10.

25. JECFA (Joint FAO/WHO Expert Committee on Food Additives) (2003) Summary and conclusions of the 61st meeting of the Joint FAO/WHO Expert Committee on Food Additives (JECFA), pp.18-22. Available at: http://www.who.int/pcs/jecfa/Sum mary61.pdf (2013.7.29).

26. Yasutake A, Matsumoto M, Yamaguchi M, Hachiya N. Current hair mercury levels in Japanese for estimation of methylmercury exposure. J Health Sci. 2004;50(2):120-5.

27. FSC (Food Safety Commission) (2005) Food safety risk assessment related to methylmercury in seafood. Available at: http:// www.fsc.go.jp/english/topics/methylmercury_risk_assessment.pdf (2013.10.3).

28. Murata K, Sakamoto M, Nakai K, Weihe P, Dakeishi M, Iwata T, et al. Effects of methylmercury on neurodevelopment in Japanese children in relation to the Madeiran study. Int Arch Occup Environ Health. 2004;77:571-9. 
29. Davidson PW, Leste A, Benstrong E, Burns CM, Valentin J, Sloane-Reeves J, et al. Fish consumption, mercury exposure, and their associations with scholastic achievement in the Seychelles Child Development Study. Neurotoxicology. 2010;31:439-47.

30. Wang Y, Chen A, Dietrich KN, Radcliffe J, Caldwell KL, Rogan WJ. Postnatal exposure to methyl mercury and neuropsychological development in 7-year-old urban inner-city children exposed to lead in the United States. Child Neuropsychol. 2014;20(5):527-38.

31. Takahashi Y, Yoshida M. Effects of mercury vapor released from dental amalgam on health and environment. St Marianna Med J. 2002;30:1-10.

32. Kawada T, Suzuki S. A review on the cadmium content of rice, daily cadmium intake, and accumulation in the kidneys. J Occup Health. 1998;40:264-9.

33. Riget F, Johannsen P, Asmund G. Baseline levels and natural variability of elements in three seaweed species from west Greenland. Mar Pollut Bull. 1997;34:171-6.

34. Watanabe T, Nakatsuka H, Shimbo S, Yaginuma-Sakurai K, Ikeda M. High cadmium and low lead exposure of children in Japan. Int Arch Occup Environ Health. 2013;86(8):865-73.

35. Choi YH, Hu H, Mukherjee B, Miller J, Park SK. Environmental cadmium and lead exposures and hearing loss in U.S. adults: the
National Health and Nutrition Examination Survey, 1999-2004. Environ Health Perspect. 2012;120(11):1544-50.

36. Gobe G, Crane D. Mini review: mitochondria, reactive oxygen species and cadmium toxicity in the kidney. Toxicol Lett. 2010;198:49-55.

37. Apostolou A, Garcia-Esquinas E, Fadrowski JJ, McLain P, Weaver VM, Navas-Acien A. Secondhand tobacco smoke: a source of lead exposure in US children and adolescents. Am J Public Health. 2012;102:714-22.

38. Koller K, Brown T, Spurgeon A, Levy L. Recent developments in low-level lead exposure and intellectual impairment in children. Environ Health Perspect. 2004;112(9):987-94.

39. Yoshinaga J, Takagi M, Yamasaki K, Tamiya S, Watanabe C, Kaji M. Blood lead levels of contemporary Japanese children. Environ Health Prev Med. 2012;17:27-33.

40. Budzt-Jørgensen E, Bellinger D, Lanphear B, Grandjean P. An international pooled analysis for obtaining a benchmark dose for environmental lead exposure in children. Risk Anal. 2013;33:450-61. 